\title{
Strengthening Industry Institute Collaboration and its Outcome
}

\author{
Dr. Siddhartha Ghosh, Dr. A Padmaja, Mr Y Praveen Kumar \\ Vidya Jyothi Institute of Technology, Hyderabad \\ ${ }^{1}$ siddhartha@ vjit.ac.in \\ 2 principalvjit@vjit.ac.in \\ ${ }^{3}$ praveenkumar@vjit.ac.in
}

\begin{abstract}
For the development of any Technical Academic Institution, better interaction between Technical Institutions and Industry is the need of the hour. These collaborations allow us to know industry needs and quality to be maintained inside academic institutes. Eventually, this allows us to make curriculum changes, adding value added courses and students get exposure to industry skills and subsequently to placements. With the advent of globalization and opening up of Indian economy to outside world, competition among industries has become tough. Industry also needs help from academic institutions to solve their engineering problems and also right people with right skill set. Looking at the rapid pace of advancements in technology, there is a need to prepare our students to the requirements of industry by exposing them to newer technologies and engineering methodologies. These objectives can only be achieved well by bridging the gap between industry and the academic institute. To strengthen in this direction, Vidya Jyothi Institute of Technology has taken a plan of establishing few Centers of Excellence (CoEs) in 5 years to enhance the technical skills of the students. To inculcate self learning among students, institute has also planned for a good number of certifications. And to do all these things, we felt the need of establishing an Industry Institute Cell (IIC) and bringing the plans into action under this banner. In this journey, the college is able to make three Centers of Excellences in its own premises, which are unique in themselves. They are Lean Center of Excellence in manufacturing practices for Mechanical, Electrical \& Electronics Engineering students, Qlik Center of Excellence in Data Analytics \& Virtusa Center of Excellence in Software Testing for Computer Science and Information Technology stream of students. This paper will throw light on the journey of establishing these three
\end{abstract}

CoEs, making hundreds of students certified and their outcomes.

Key Words: Industry Institute Interaction, Curriculum, Center of Excellence, Placements and Graduating Engineers

\section{Introduction}

The Government, Industry and Academia are three different worlds with max social impact. All three have different purposes and approaches. However, the rapid pace of change across the globe has compelled them to function in sync with each other to address some of the major challenges of higher education landscape.

According to National Employability Report, the education sector in India is poised to witness major growth in the years to come, as India will have second largest graduate talent pipeline globally by the end of 2020 . India's economy is also expected to grow at a rapid pace; rapid industrialization would require a workforce of around 250 million by 2030; India could potentially emerge as a global supplier of skilled manpower. However, despite these encouraging statistics, a major segment of Indian graduates remain unemployable according to the above report. ${ }^{1}$ India skills report says that $47 \%$ of engineering graduates are employable. ${ }^{2,11}$

Looking at these statistics of un-employability, there is a need to strengthen Industry Academic Institutions collaborations..$^{3,4,5,9,10}$ An attempt has been made to establish Centers of Excellence in the campus. At VJIT, we were pretty clear about the main motto of establishing CoEs which is nothing but to fill critical skill gaps and benefit the students and faculty. The other reasons were better industry collaborations, enhancing research scope in UG level, better opportunities for students in internships and placements ${ }^{12}$. For a private engineering college, the journey has not been easy, though not impossible. In 
working towards this direction, a proper ground work is done in the year 2016 .

The Industry-Institute- Cell (IIC) of the institute is dedicated to promote a close interaction of industry and various departments of the institute. The cell is primarily a bridge between the industry, the real world, and the institute. Exposure to industry faculty will be able to guide students about latest industrial practices. IIC prepares engineering students for jobs in multinational companies, by exposing them to newer technologies and engineering methodologies. This bridges the gap between industry and the academic institute.

VJIT has setup an Industry-Institute- Cell for the above purpose under the leadership of an expert team who has rich experience and exposure in both academics and industry. The ultimate aim of imparting professional education is to prepare the students to be industry-ready by providing exposure to current industry practices and to secure job in any platform. The IIC established in VJIT is determined in acquiring the objectives mentioned.

\section{Objectives of the Practice}

- To enhance the relationship between the Institute and Industry.

- To promote participation of industry personnel in the development of curricula \& high quality student projects. E.g. Member of Board of Studies (BOS).

- Memorandum of Understanding between the Institute and Industries

- Visits of industry experts and practicing engineers to the Institute for seeing research work and laboratories, discussions and delivering lectures on industrial practices, trends and experiences.

- Visits of faculty to industry for study and discussions or delivering lectures

- To facilitate industrial training for students, internship programs and students' study tour programs

- To encourage entrepreneurial activities among the students

- To support consultancy/ training services using the institutional expertise

- To identify the industries for support in academic activities through Corporate Social Responsibility (CSR) programs
With sustained efforts of IIC team, VJIT could establish the following listed areas of COEs.

- Center of Excellence in Data Analytics with Qlik India, USA

- Center of Excellence in Software Testing with Virtusa, Chennai

- Center of Excellence in the field of Lean Manufacturing with Lean Technocrats, Hyderabad

\section{Evidence of Success}

1. Center of Excellence in Software Testing with Virtusa : Established in the year 2017

Objective: Virtusa would be training VJIT faculty and students in Software Testing, make them certified and hence industry ready.

- Three of our faculty have been trained and certified under the guidance of Virtusa expert team.

- The certified faculty members now guide Virtusa selected students for learning Software Testing, SQL and Java and help them in taking 2 certification.

- All the students selected students are done with ISTQB Testing and OJCP Java certification before joining Virtusa.

\begin{tabular}{|l|l|l|l|}
\hline S.No. & Parameter & $\mathbf{2 0 1 9 - 2 0}$ & $\mathbf{2 0 1 7 - 1 8}$ \\
\hline 1. & Faculty Trained & 3 & 3 \\
\hline 2. & Students Placed & 24 & 20 \\
\hline 3. & $\begin{array}{l}\text { Certified in } \\
\text { ISTQB/OJCP }\end{array}$ & 27 & 20 \\
\hline
\end{tabular}

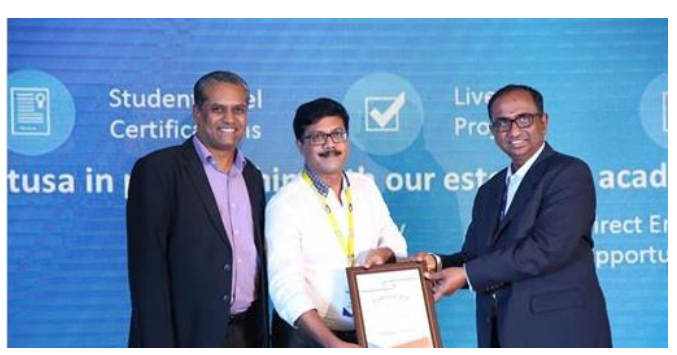

Fig 1 : Virtusa CoE Certificate handed over to VJIT by Virtusa at Chennai 


\begin{tabular}{|l|l|l|l|l|}
\hline S.No. & Parameter & $2019-20$ & $2018-19$ & $2017-18$ \\
\hline 1. & $\begin{array}{l}\text { Faculty } \\
\text { Certified }\end{array}$ & Nil & 2 & 2 \\
\hline 2. & $\begin{array}{l}\text { Students } \\
\text { enrolled for the } \\
\text { course }\end{array}$ & 225 & 125 & Nil \\
\hline 3. & $\begin{array}{l}\text { Certified in } \\
\text { Data analytics }\end{array}$ & $\begin{array}{l}\text { Learning } \\
\text { Now }\end{array}$ & 101 & Nil \\
\hline 4. & Projects & $\begin{array}{l}\text { Not yet } \\
\text { Confirmed }\end{array}$ & $\begin{array}{l}\text { B.Tech and } \\
\text { M.Tech } \\
\text { Projects: 46 }\end{array}$ & 2 \\
\hline
\end{tabular}

To find the effect of the Virtusa CoE among students community we have made a statistical survey and it's found that the students who have joined Virtusa as an outcome of Virtusa $\mathrm{CoE}$ at VJIT are more efficient than the other freshers joined at the same time.

A Centre of Excellence is set up in the 2017 supported by Qlik India, a based USA Software Company as a part of Industry Institute Interaction

Objective: The objective of this center is to equip students and faculty in Qlik tools with self passed online course and certification.

- The center is an unique concept by its own as this is the only one Centre of Excellence of Qlik in India.

- The concept, its implementation and the outcome (certified Qlik Students) is highly appreciated by the news media, other software company and Qlik USA a\& India.

- The Qlik CoE offers Rs.20000 worth course fee and $\$ 250$ worth certification for free of cost to the VJIT students.

- Faculty and students implementing projects using Qlik and also publishing papers as on today.

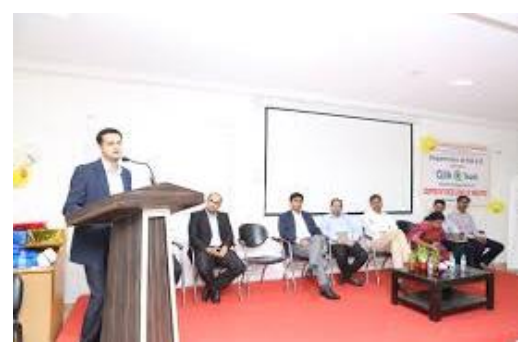

Fig2: Qlik CoE Inauguration at VJIT

Table: 1 Outcome of Qlik Center of Excellence
Dr. Siddhartha Ghosh the SPOC of this Center has been awarded with Qlik Luminary of 2018 award by Qlik.

\section{Qlik opens data analytics centre}
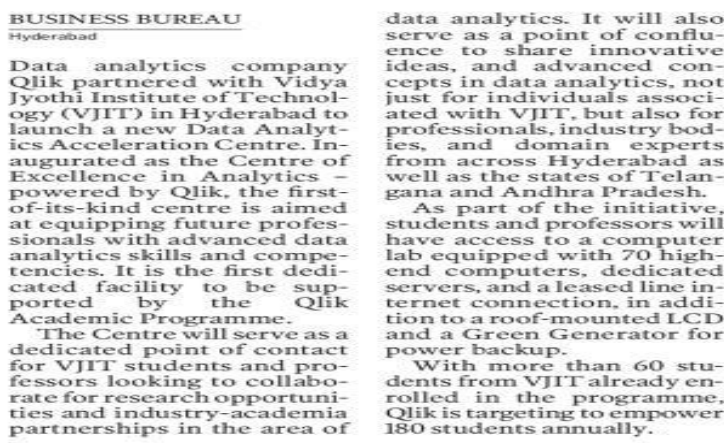

Fig3 : Qlik CoE news in Print Media

The Qlik journey of VJIT is very interesting and starting from 50 students in 2018 in 2019 total 101 are done with certification. The number of jobs achieved by the students also increased.

\section{Center of Excellence in the field of Manufacturing with Lean Technocrats}

Objective - The objective of establishing Lean Center of Excellence in Manufacturing and Production is to strengthen the core branches like Mechanical, Electrical and Electronics and make the students industry ready.

- Lean - "The Means for leveraging growth". The Lean Technocrat certification is exclusively for Mechanical, Electrical and Electronics Engineering students. It typically focuses on manufacturing industries for top-line growth.

- As a part of Lean CoE the students does a 15 fulldays course by the Lean Technocrats Experts, learn the art of manufacturing using Lean concepts and implements industry level projects using Lean. Finally the students get certified through written test and interview.

- The course outcome is - about 50-70 core job in the top manufacturing companies from VJIT

Lean $\mathrm{CoE}$ for core engineering branches has helped the VJIT mechanical, Civil and Electrical core stream students to get better jobs in the market. The Lean certified students who have gone for higher studies also mentioned 
that the Lean concepts had helped them to apply the concepts in their masters course also.

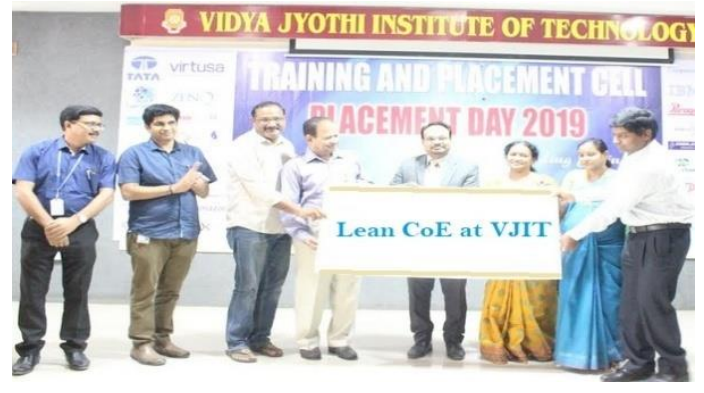

Fig4: Inauguration of Lean $\mathrm{CoE}$

Table 2: Outcome of Lean Technocrats center of Excellence

\begin{tabular}{|l|l|l|l|l|}
\hline $\begin{array}{l}\text { S.No } \\
.\end{array}$ & Parameter & $\mathbf{2 0 1 7 - 1 8}$ & $\mathbf{2 0 1 8 - 1 9}$ & $\mathbf{2 0 1 9 - 2 0}$ \\
\hline 1. & Students enrolled & 31 & 90 & 100 \\
\hline 2. & $\begin{array}{l}\text { Certified in Lean } \\
\text { Manufacturing }\end{array}$ & 26 & 84 & Ongoing \\
\hline 3. & Placed/Internships & 20 & 56 & Ongoing \\
\hline 4. & Companies & $\begin{array}{l}\text { Schneider/ } \\
\text { Denso/ } \\
\text { Dalal Plastic/ } \\
\text { Everest }\end{array}$ & $\begin{array}{l}\text { Thermocables/ } \\
\begin{array}{l}\text { Rexnord/ } \\
\text { Schneider } \\
\text { Electric } \\
\text { /Lean-Techno }\end{array}\end{array}$ & $\begin{array}{l}\text { 130 are } \\
\text { ready to } \\
\text { enroll }\end{array}$ \\
\hline 5. & Lean Projects & 31 & 97 & - \\
\hline
\end{tabular}

\section{Other Industry Collaborations}

\section{MoU with Cyient}

MoU with Cyient for recruitment and training of students, and training in AI Machine learning for faculty.

IoT Maker space association with Techno Lexis and TASK

Objective: Main objective is to foster an active collaboration between the Academia, Students and Industry - open all vistas of learning, imbibe a culture of exploring, probing and experimenting and effectively transforming the student force into an industry-ready engineering workforce/ thought leaders/ innovators and entrepreneurs. Maker Space helps in facilitating industry participation and build confidence amongst students to collaborate with industry in developing innovative solutions, participate in internships and placements, and offers an opportunity to be a part of the Innovation /entrepreneurship ecosystem.

It will also help in improving skill development and increasing the quality and quantum of placements.

\section{Outcome}

- Hackathons and workshops have been conducted to develop products of IOT

- Internships for 21 Students in IoT based companies

- Students placed in IOT based companies Lenovate Solutions Bangalore \& Motivity Labs Hyderabad

\section{MoU with Ajna Networks for Recruitment}

- $\quad$ One of the Alumni of ECE department: Recruited 17 students from VJIT 2018

MoU has been signed with Cetriport to make VJIT as a Microsoft Certification Test Center

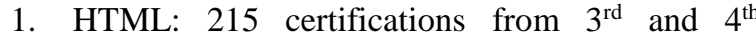
Years.(CSE/IT and ECE branches)

2. Database: 125 cortication from $3^{\text {rd }}$ and $4^{\text {th }}$ Years. (CSE/IT and ECE branches)

3. Auto CAD: 385 Certifications from $3^{\text {rd }}$ and $4^{\text {th }}$ Years (Civil/Mechanical and EEE Branches)

\begin{tabular}{|l|l|}
\hline CERTIPORT Outcome & Total \\
\hline & 214 \\
\hline HTML (CSE, IT, ECE) & 124 \\
\hline Database (CSE, IT, ECE) & 384 \\
\hline $\begin{array}{l}\text { Auto CAD } \\
\text { (CIVIL, EEE, MECH) }\end{array}$ & 3 \\
\hline
\end{tabular}

\section{Problems Encountered}

- In a few of the cases (of the CoE) the related Certifications are expensive and is not an affordable amount for many of the students.

- It is also identified as a major problem at the beginning that the $\mathrm{CoE} s$ cannot run without skilled and certified internal faculty members. Means just based on only industry input, the $\mathrm{CoE}$ $s$ cannot stand for long time. After understanding this point, initiatives have been taken to improve faculty skills and to certify the faculty in this regard.

\section{Resources required to implement practices}


- Good labs with computers and required software and hardware

- Journals and books for students to work in the areas concerned

- Good inter and intra human resource

- Showcasing the acquired skills by the students.

\section{Overall outcome with the collaboration of industries}

- Students are trained as per the industry needs and exposed to the latest trends of Industry.

- Faculty also has been exposed to the newer technologies, which have been included in the curriculum.

- Students are placed in good companies / secured internships to carry out major projects

- Sharing of knowledge by the faculty in their respective domains to the industry results in collaborative research projects.

\section{Conclusion}

The collaboration between technical institutions and industry is not new, but the way market demand is changing for the best fresh candidates, time has come that each one of us (read - academic institutions) establishes strong Industry Collaborations. The mantra of the hour for us is IIC, CoEs, MoUs and Certifications to fill the best skill gap and enable the students in their dream areas. The skills are not just for job market, but they are equally must for higher studies at foreign universities, and also for entrepreneurship. The journey of VJIT under the umbrella of IIC is opening new gates for it and we feel we are just at the beginning, and hence the need of the hour is to build better relation with the industry. The result till date is highly acceptable and will cherish our young hearts. The overall motto is nothing but the benefit of the students.

\section{References:}

1.https://digitallearning.eletsonline.com/2019/03/governm ent-industry-academia-collaboration-key-to-qualityhigher-education/ 2.https://www.peoplestrong.com/india-skills-report-201947-engineering-graduates-employable-ap-leads-withhighest-employability-rate/

3. A roadmap to effective industry-institute collaboration, https://www.researchgate.net/publication/294087340

4. What makes industry-university collaboration succeed? A systematic review of the literature, Journal of Business Economics, March 2019, Volume 89, Issue 2, pp 221-250

5 .An overview on industry-institute collaboration on the quality of education in engineering institutions, 2010 https://www.researchgate.net/publication/294085396

6.http://www.ametjournal.com/attachment/Ametjournal5/1 1\%20Braha19-8-13.pdf

7.http://inskills.co.in/download/General/FICCINMIMS\%20report\%20on\%20Industry$\% 20$ Academia $\% 20$ Convergence $\% 20$ 'Bridging $\% 20$ the $\% 20$ Skill\%20G

8.https://www.nasscom.in/sites/default/files/NASSCOM_ Annual_Report_2018-19.pdf

9.Padma M.C., Sridhar V. (2015) Role of IndustryInstitute Interaction to Promote Education and Entrepreneurship. In: Natarajan R. (eds) Proceedings of the International Conference on Transformations in Engineering Education. Springer, New Delhi

10. Arunsimha, Anitha, "Industry-Academia Interface: perspectives and practices", The ICFAI University Press, 2008, P5, 6

11. National Skill Development Corporation Report -2012

12. Strengthening Industry Institute Interaction (III) for improvement in campus placement and industry Tie-up of Automobile Engineering Department in RIT: A Quality Circle Approach,Nilesh Satonkar *, Pankaj Ghatage , Ganesh Kavade, Pradip Patil , Anuradha Gaikwad, Sandip Desai , Satyajit Patil,DOI: 10.16920/jeet/2017/v30i4/114105 